Terr. Atmos. Ocean. Sci., Vol. 18, No. 5, 975-994, December 2007

\title{
Major Factors Controlling Arsenic Occurrence in the Groundwater and Sediments of the Chianan Coastal Plain, SW Taiwan
}

\author{
Kuan-Yu Chen ${ }^{1}$ and Tsung-Kwei Liu ${ }^{1}$ *
}

(Manuscript received 16 May 2007, in final form 8 June 2007)

\begin{abstract}
The Chianan coastal plain in southwestern Taiwan has long been well known for the prevalence of black-foot disease during the period 1961 to 1985. This disease resulted from drinking groundwater rich in arsenic and dissolved humic substances. However, the occurrence of arsenic and its controlling factors have not yet been studied in detail. Water samples from a total of 86 newly established monitoring wells and sediment samples from 28 fully cored boreholes were analyzed in this study to investigate major chemical [such as $\mathrm{SO}_{4}{ }^{2-}, \mathrm{Cl}$, redox potential (Eh), $\mathrm{pH}$, and ${ }^{14} \mathrm{C}_{\text {DIC }}$ ages] and geological (such as depositional environment, grain size and arsenic content of sediments) factors which may control the distribution of arsenic in groundwater of the upper $\sim 300$-m thick strata. This study shows that arsenic concentrations of almost all groundwater samples exceed the $0.01 \mathrm{mg} \mathrm{L}^{-1}$ limit of the WHO guidelines, with the highest values up to $\sim 1.2 \mathrm{mg} \mathrm{L}^{-1}$. Only the deep aquifers $(>50 \mathrm{~m})$ deposited before Holocene transgression contain groundwaters with relatively high arsenic contents $\left(>0.1 \mathrm{mg} \mathrm{L}^{-1}\right)$. All the arsenic-rich groundwaters are under strongly reducing conditions with low Eh $(<110 \mathrm{mV})$ and low $\mathrm{SO}_{4}{ }^{2-}$ (nearly all $\left.<2 \mathrm{mg} \mathrm{L}^{-1}\right)$. The different combination of $\mathrm{As}, \mathrm{Fe}$, and $\mathrm{SO}_{4}{ }^{2-}$ concentrations of groundwater reflect various redox potentials. The reductive dissolution of As-rich $\mathrm{Fe}$-(hydr)oxides is believed to be the major source of As in the groundwater, but the contents of $\mathrm{SO}_{4}{ }^{2-}$, humic substances and residence time of water are also responsible for the variation of dissolved As in the Chianan coastal plain.
\end{abstract}

(Key words: Arsenic, Blackfoot disease, Groundwater, Coastal plain, Taiwan)

\footnotetext{
${ }^{1}$ Department of Geosciences, National Taiwan University, Taipei, Taiwan, ROC

* Corresponding author address: Prof. Tsung-Kwei Liu, Department of Geosciences, National Taiwan University, Taipei, Taiwan, ROC; E-mail: liutk@ntu.edu.tw
} doi: 10.3319/TAO.2007.18.5.975(TT) 


\section{INTRODUCTION}

The occurrence and factors controlling the arsenic contents in groundwater have drawn much attention in recent years (e.g., Hering and Kneebone 2001; Inskeep et al. 2002; Mandal and Suzuki 2002; Smedley and Kinniburg 2002; Anawar et al. 2003; Ahmed et al. 2004; Huntsman-Mapila et al. 2006; Pedersen et al. 2006; Varsanyi and Kovács 2006). The Chianan coastal plain in southwestern Taiwan (Fig. 1) has been well known for the occurrence of a peculiar peripheral vascular disorder in humans called "black-foot disease". This serious chronic disease was first reported between 1910 and 1920 (Kao and Kao 1954), but awareness of the problem did not begin until 1960s (e.g., Tseng et al. 1961) when the disease became endemic in coastal areas. The cause of the disease was later attributed to high arsenic (Chen and $\mathrm{Wu}$ 1962) or fluorescent humic substances (Lu et al. 1975; Lu 1990a, b) in groundwater used for drinking. It was reported that both black-foot disease and arsenism was limited to people drinking deep well water that contained a variable but high concentration of arsenic $(0.10$ $1.81 \mathrm{mg} \mathrm{L}^{-1}$; Tseng et al. 1961). Since then, intensive medical studies on the disease have been carried out (e.g., Chen et al. 1988). However, the occurrence and the controlling factor(s) of

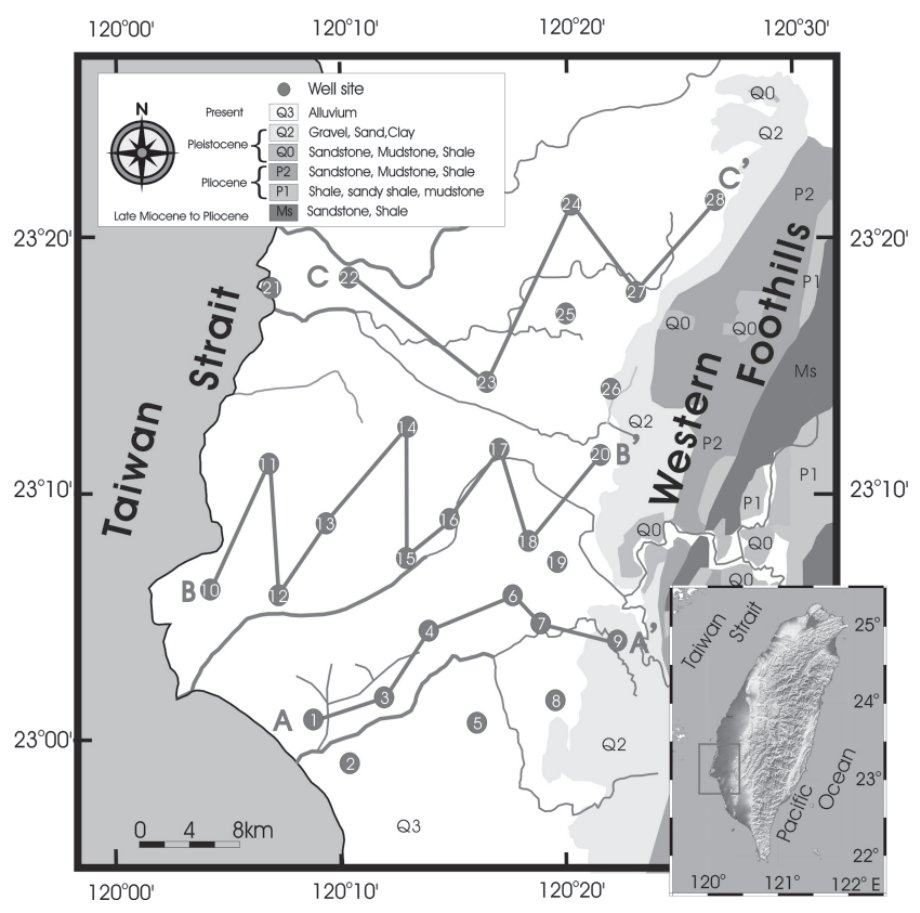

Fig. 1. Groundwater well locations and the simplified geologic map around the Chianan coastal plain in southwestern Taiwan. Profiles AA', BB', and CC' shown in Fig. 2 are also shown. 
arsenic enrichment in the groundwater were not examined in detail. The water samples analyzed by early studies were mainly collected from private wells, and the depths of each well screen (i.e., tapped portions of well casings) were not known exactly and/or the potential existed for water to be a mixture from different aquifers.

Over the past few decades, excess pumping of groundwater in the plain has resulted in environmental problems such as seawater intrusion and land subsidence. To enable better development and management of the groundwater resource and better understanding and protection of water quality, a Groundwater Monitoring Network (GMN) program, involving intensive drilling for sediment cores and construction of monitoring wells, has been undertaken in recent years. This study uses data provided by 28 boreholes, each about $250 \sim 300 \mathrm{~m}$ deep, and 86 wells which were drilled during the GMN program. The main results obtained from analyses of the core sediments and water samples are presented herein, with a focus on major hydrochemical and hydrogeological factors controlling the spatial distribution of arsenic in the groundwater.

Taiwan is a young and active mountainous island formed due to the collision between the Luzon volcanic arc of the Philippine Sea plate and the continental margin of the Eurasian plate (Ho 1986; Teng 1987). The backbone of the island is mainly composed of metamorphosed rocks, which are surrounded by Tertiary sedimentary rocks of the foothill zones. The western outskirts of the island are well developed tablelands and coastal alluvial-deltaic plains formed during the Quaternary. The Chianan coastal plain (Fig. 1) in southwestern Taiwan covers an area of ca. $2100 \mathrm{~km}^{2}$ and is a tectonically active subsiding depression formed at the foreland of the actively uplifting mountain belt on the east ( Liu et al. 1997). Carbon-14 dates show that sediment accumulation rates are rather high $\left(\sim 1 \mathrm{~cm} \mathrm{yr}^{-1}\right)$ and the upper-most 100-m thick layer was deposited during the last 10000 years. The present ground surface slopes westward with a

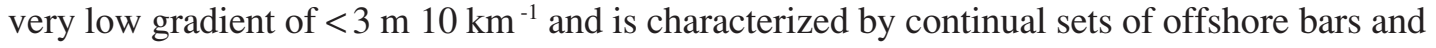
lagoons along the coast.

It has been found that the unconsolidated strata of this plain (more than $1000 \mathrm{~m}$ in thickness) are mainly composed of poorly sorted alternating beds of fine-grained clastic sediments such as clay, silt and fine sand (Oung et al. 2001). These sediments were deposited in mixed alluvial and delta environments such as fluvial flood plains, estuaries, lagoons, and shallow marines from the Late Pleistocene onwards (Wu 1999). These sediments were mainly derived from the very thick $(\sim 5000 \mathrm{~m})$ sequence of slightly consolidated Pliocene marine mudstones (namely Kutingkeng Formation) exposed on the hills to the east (Ho 1986).

\section{SAMPLING AND ANALYTICAL METHODS}

\subsection{Groundwater}

At each monitoring site, a full-cored borehole was drilled first for obtaining subsurface lithological information, which was then used as the base for determining $2 \sim 4$ depth ranges for installing screens for monitoring wells. Each well was linked through the screen to only a single aquifer. All these wells were established for water-quality sampling and subject to continuous water-level monitoring. 
During April to May, 2004, a total of 86 well water samples from 28 sites (Fig. 1) were collected for this study. At least three times the volume of stagnant water within the well casing was pumped out and discarded before taking samples. On-site measurements included $\mathrm{pH}$, redox potential (Eh), and specific electric conductivity (EC). Of which, Eh and $\mathrm{pH}$ were determined by Sentron $1001{ }^{\circledR}$ Eh-pH meter, while EC was measured by an Orion $130^{\circledR}$. All samples were monitored in anaerobic flow cells during purging until stable readings were obtained. Water samples were collected for subsequent chemical and isotopic analysis only after $\mathrm{pH}$ and $\mathrm{EC}$ became stable, i.e., fluctuations of $\mathrm{pH}$ and relative $\mathrm{EC}$ were less than 0.1 and $5 \%$, respectively.

Each water sample was divided into several portions according to the needs of chemical analyses. Waters for cation analyses were filtered through $0.45-\mu \mathrm{m}$ acetate filters and acidified with nitric acid until $\mathrm{pH}=2$. Samples were then kept in ice boxes and delivered to the laboratory within 24 hours. Dissolved Fe and Mn were measured by atomic absorption spectroscopy using a Perkin-Elmer AAnalyst $100^{\circledR}$. For arsenic analysis a flow injection hydride analysis system FIAS- $400{ }^{\circledR}$ was attached to the same spectrometer. Concentrations of $\mathrm{SO}_{4}{ }^{2-}$ and $\mathrm{Cl}^{-}$ were determined by ion chromatograph with a Dionex-120 ${ }^{\circledR}$. About 50 liters of each water sample were collected for precipitating dissolved inorganic carbon (DIC) for ${ }^{14} \mathrm{C}$ dating using the procedures described by Hackley et al. (1992) and Liu (1995). The uncertainties for As and $\mathrm{SO}_{4}{ }^{2-}$ are $3 \%$, and that for $\mathrm{Cl}^{-}$is $2 \%$.

\subsection{Sediments}

The sedimentary environments of the uppermost 250 -m thick deposits sampled were identified by sedimentary structures such as cross beddings, ripple marks, plane beddings, characteristic lithologies (such as rootlets and brownish to reddish paleo-soil) and fossils (such as mollusks, foraminifers, and calcareous nano-fossils) (Wu 1999). Terrestrial environments were characterized by paleo-soil, rootlets and having no marine fossils. In contrast, marine environments were characterized by foraminifers and nanofossils. The transitional environments, such as estuary, lagoon, and marsh between terrestrial and marine environments, were identified by brackish shell fossils including: Certhideospilla djadjariensis (Martens), Crassostrea gigas, Placuna placenta, Bartillaria, and oysters. Peat layers and weathered variegated mud fragments were often found in marsh environments. Abundant marine fossils and trace fossils such as Ophiomorpha and Skolithos were often found in shallow open marine (shoreface) environments (Reineck and Singh 1980).

The depositional environments and arsenic contents of sediments from the boreholes at Tainan (site $\mathrm{CN}-1$ ) and Hsiaying (site $\mathrm{CN}-23$ ) were studied in particular detail. Except the uppermost brownish-yellow soils (mostly $\leq 5 \mathrm{~m}$ thickness), the clay-silt-fine sand strata of the Chianan plain are light- to dark-grey in color, indicating that the sediments and groundwater were under reducing conditions. Accordingly, efforts were made to avoid sampling discernible oxidation portions such as anything yellowish in color due to exposure to the atmosphere. In the field, each core sediment sample for arsenic extraction analysis was pushed directly into a $30-\mathrm{cm}$ long thick-walled plastic pipe, immediately sealed on both ends, and stored under $4^{\circ} \mathrm{C}$. Each 100-g sample for chemical extraction analysis was taken from the middle inner part of a 
core segment by scraping the outer sediments, and put into a high density polyethylene centrifuge tube. Then the samples were dried with a freeze-vacuum chamber before chemical extraction analysis. At present, there is no well accepted standard method for single or sequential extractions of As in soil and sediments (e.g., Keon et al. 2001; Montperrus et al. 2002). In this study, arsenic associated with relatively mobile phases [Fe-Mn-(hydr)oxides and organic matter] in the sediments was extracted by the method developed by Ellwood and Maher (2003). Typically, $0.1 \mathrm{mg}$ of sediment was weighed out into centrifuge tube to which $10 \mathrm{ml}$ of a mixture (abbreviated as PHH solution) of $0.5 \mathrm{M}$ of phosphoric acid and $0.1 \mathrm{M}$ of hydroxylamine hydrochloride $\left(\mathrm{NH}_{2} \mathrm{OH} \cdot \mathrm{HCl}\right)$ were added. Aliquots of the supernatant were removed and usually stored overnight at $4^{\circ} \mathrm{C}$ until analysis.

In addition to the one-step extraction described above, the core sediments from $\mathrm{CN}-1$ were also analyzed by the sequential extraction method proposed by Tessier et al. (1979) and $\mathrm{Li}$ et al. (1995). This was originally intended to reveal the amount of arsenic associated with: (1) easily exchangeable matter and carbonates, (2) Fe-Mn-(hydr)oxides, and (3) sulfide and organics. The first fraction was extracted by $1 \mathrm{M} \mathrm{CH}_{3} \mathrm{COONa}$. A mixture of $\mathrm{NH}_{2} \mathrm{OH} \cdot \mathrm{HCl}$ in $25 \%$ acetic acid, as an acidic and reductive solvent, is reasonably selective in extracting secondary amorphous Fe and Mn(hydr)oxides and associated arsenic (Varsányi and Kovács 2006). This solvent also removed the elements weakly attached to organic matter. Finally, sulfideassociated arsenic and organics were extracted with a mixture of $0.02 \mathrm{M} \mathrm{HNO}_{3}, 30 \% \mathrm{H}_{2} \mathrm{O}_{2}$, and 3.2 $\mathrm{M} \mathrm{CH}_{3} \mathrm{COONH}_{4}$. The arsenic contents of the extraction solutions were also determined by atomic absorption spectroscopy mentioned above.

\section{RESULTS AND DISCUSSION}

\subsection{Hydrogeological Framework}

The hydrogeological framework of the Chinan plain is shown in Fig. 2. The directions of regional groundwater flows basically follow the three main streams of this plain. Based on regional lithology, the upper 250-m thick sediments are divided into four aquifer units (i.e., Aquifers $1 \sim 4$ ), each of them comprises an aquifer and an overlying aquitard. The correlation of the aquifers along each profile was essentially based on the depth and partly on the lithologic sequence because the strata are roughly horizontal. It is also obvious that the uppermost 300-m thick sequence of mixed alluvial and marine strata was deposited in response to sealevel changes brought about by global glacial cycles during the late Quaternary as evidenced by ${ }^{14} \mathrm{C}$ ages. From a regional hydrogeological point of view, coarser sediments of the aquifers represent higher energy environments during periods of regression or "low-stand" sea-levels, while sediments of the aquitards were mainly deposited during high sea-level stands when transgression occurred, especially during the last one between 12 and $6 \mathrm{Ka}$.

\subsection{Distributions of Arsenic and Other Geochemical Parameters}

The analytical results of $\mathrm{Eh}, \mathrm{pH}, \mathrm{As}, \mathrm{Fe}, \mathrm{SO}_{4}{ }^{2-}$, and $\mathrm{Cl}^{-}$of the groundwater samples are shown in Fig. 3. The $0.1 \mathrm{mg} \mathrm{L}^{-1}$ of arsenic concentration, which was found to be the lower 

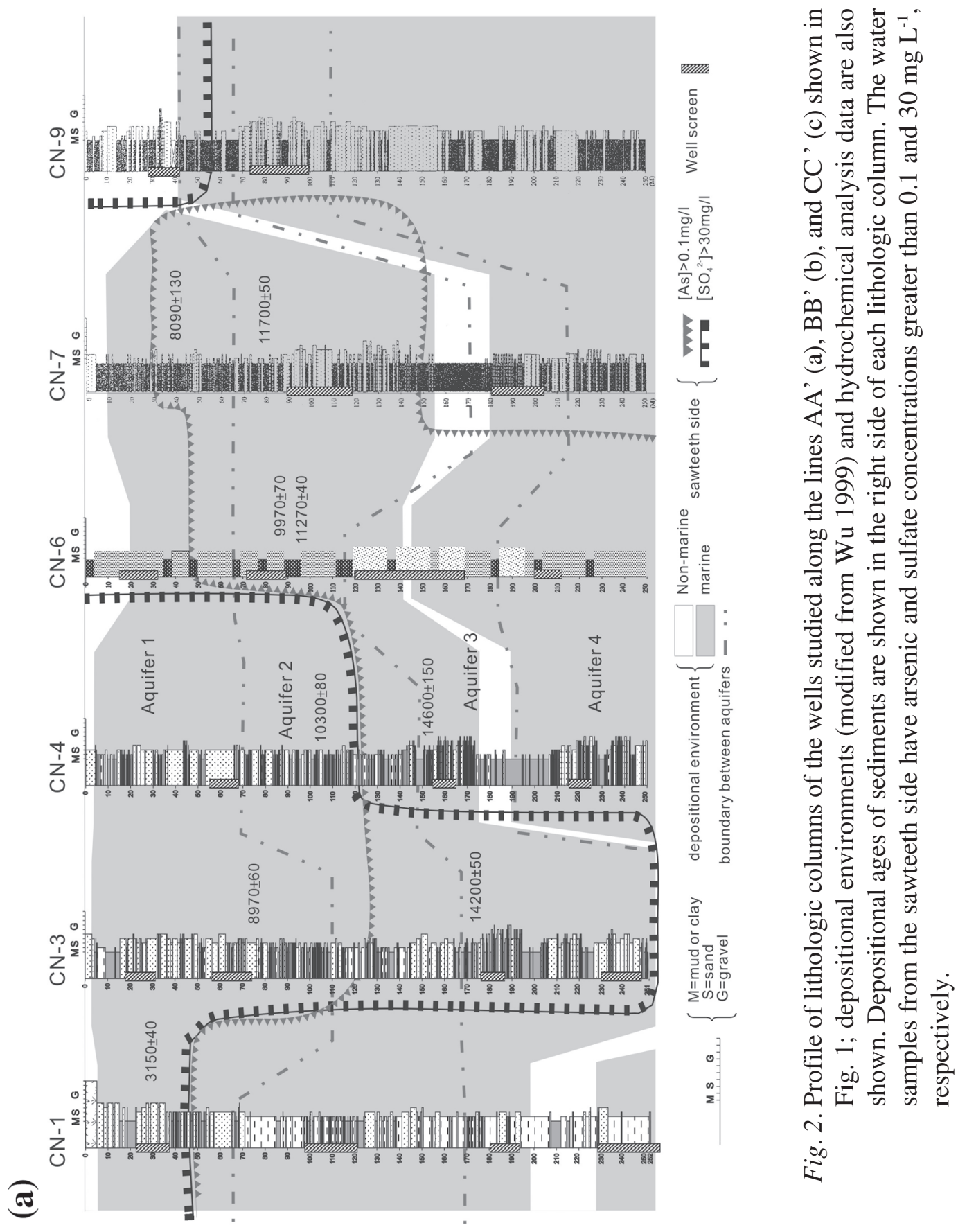


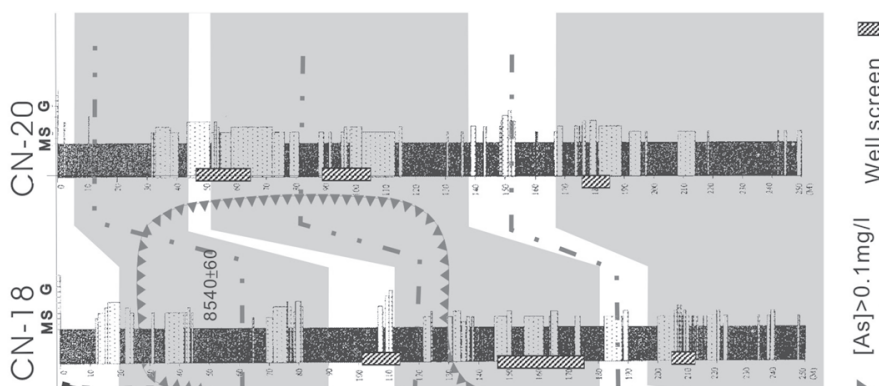

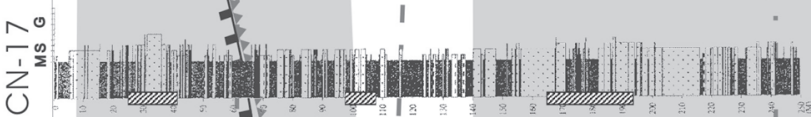
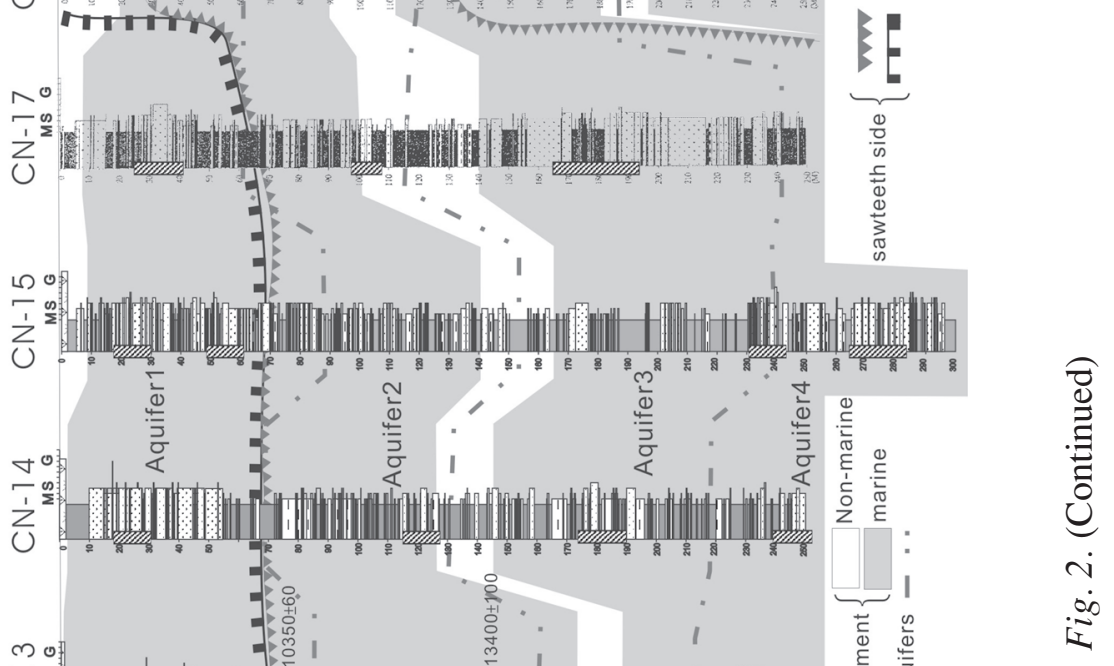

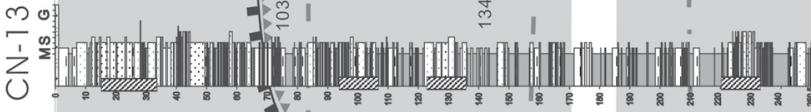
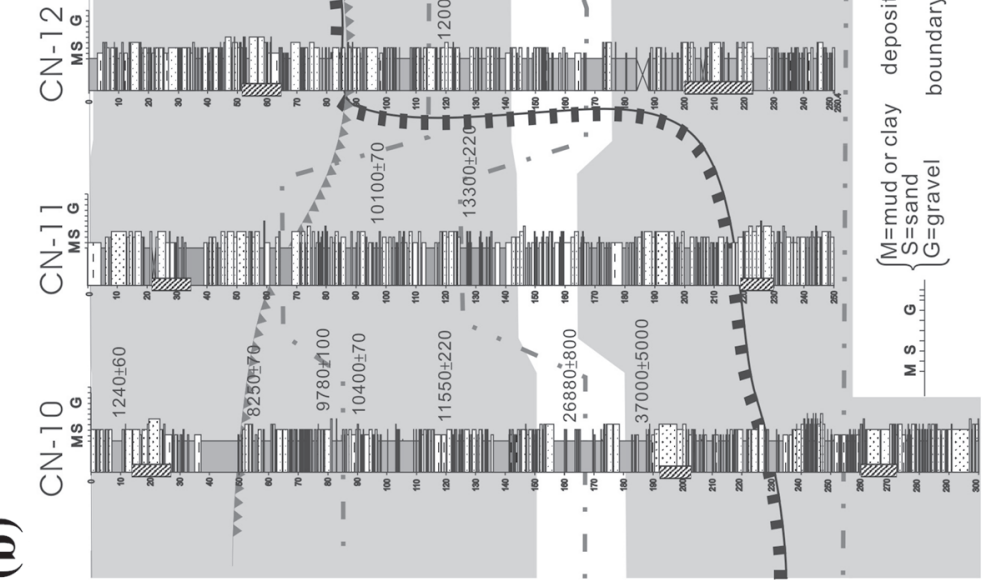


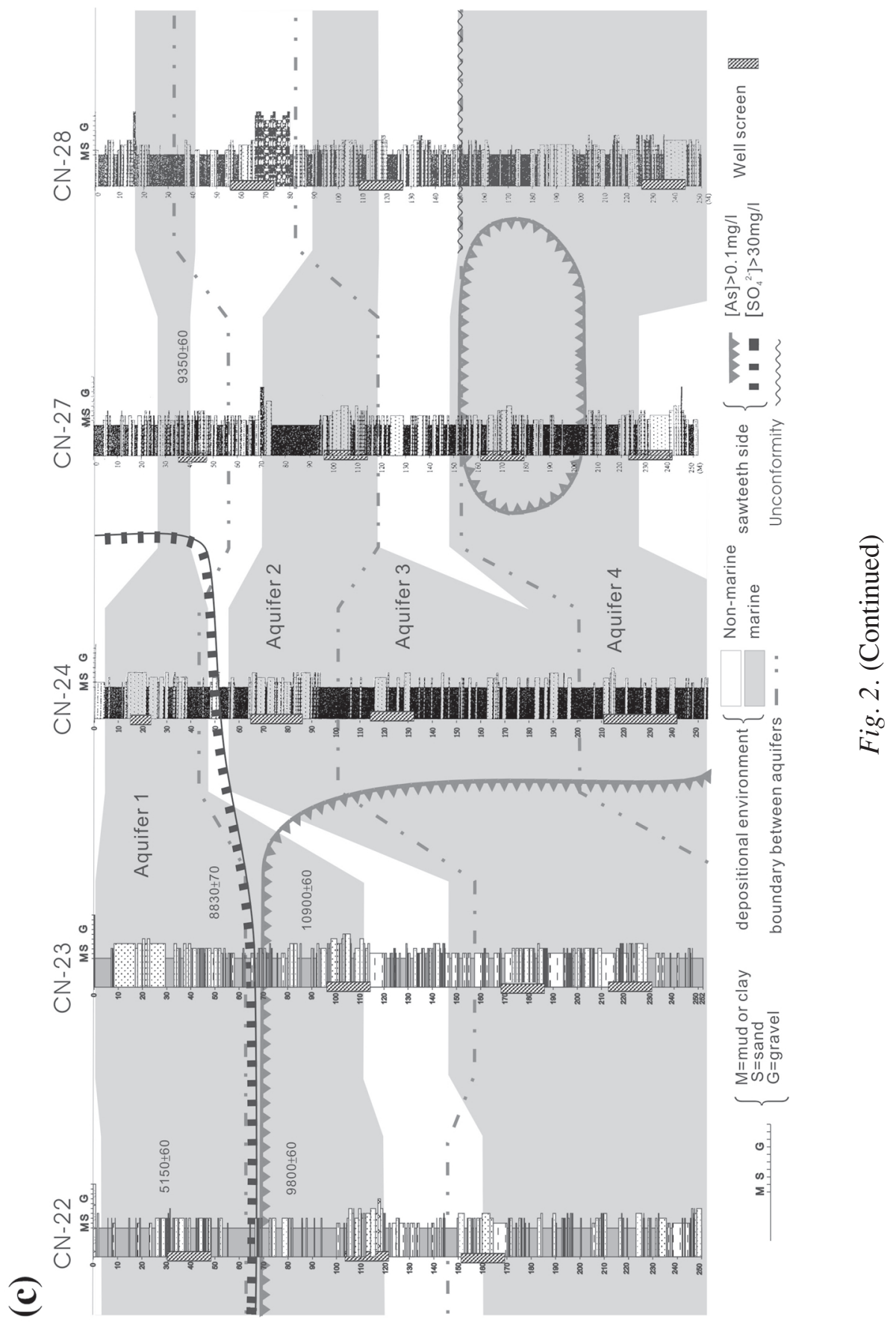




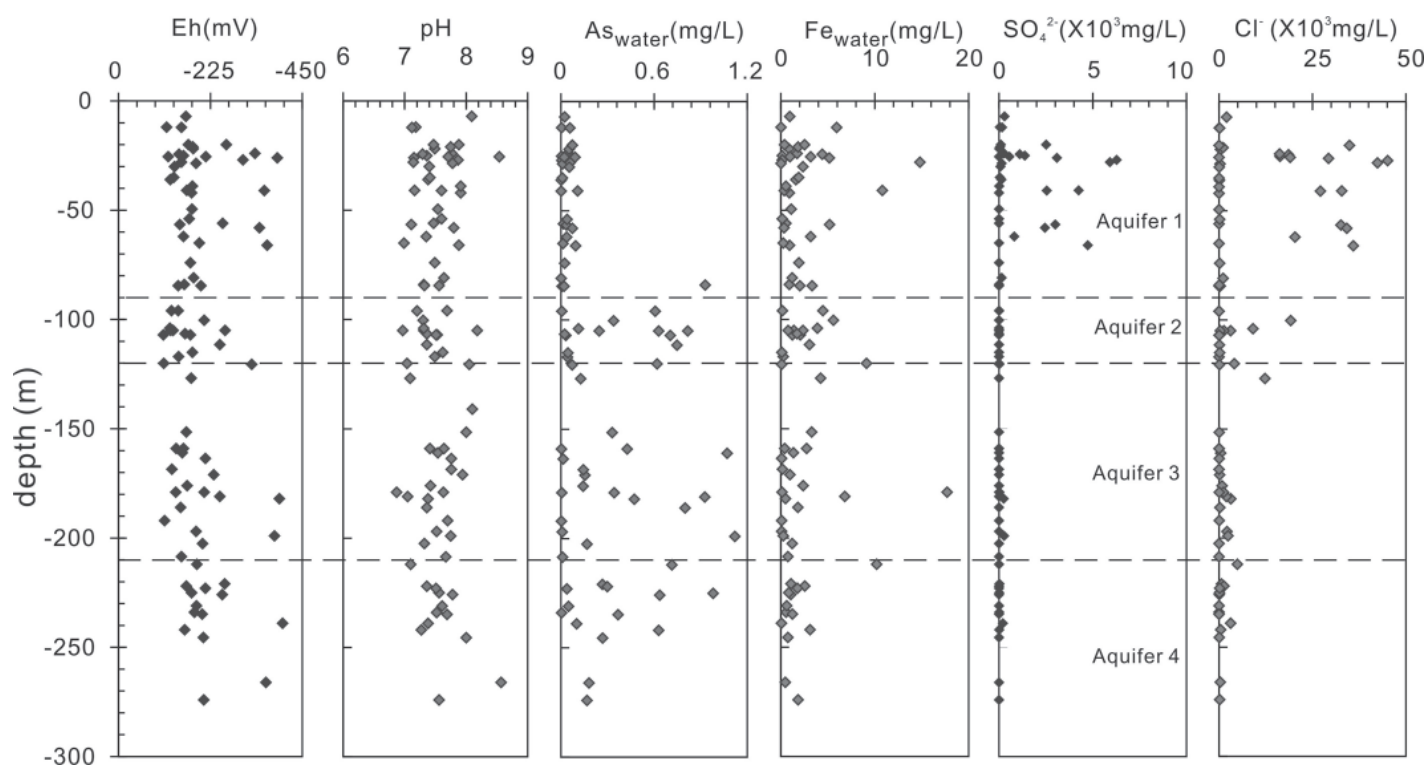

Fig. 3. Variation of $\mathrm{Eh}, \mathrm{pH}, \mathrm{As}, \mathrm{Fe}$, and $\mathrm{SO}_{4}{ }^{2-}$ concentrations vs. depth for groundwater from the Chianan plain.

threshold for causing noticeable clinical symptoms of arsenic poisoning during the most serious period (1940s $\sim 1970$ s) of the disease, is used in this study to define high arsenic contents. The aquifers on the triangular sawteeth side in Fig. 2 have higher than $0.1 \mathrm{mg} \mathrm{L}^{-1}$ of arsenic. It is evident that almost all high-arsenic waters occur in the deeper and down-gradient (discharging) side of each profile. The water samples from shallow Aquifer 1 are low in arsenic content, generally lower than the previous drinking water standard $\left(0.05 \mathrm{mg} \mathrm{L}^{-1}\right)$. In contrast, water samples from the deeper aquifers (2,3, and 4), except those from the eastern (recharging) areas, have arsenic concentrations much higher than $0.05 \mathrm{mg} \mathrm{L}^{-1}$. Similarly, an arbitrary value of $30 \mathrm{mg} \mathrm{L}^{-1}$, which is equivalent to $\sim 1 \%$ of $\mathrm{SO}_{4}{ }^{2-}$ abundance of standard sea water $\left(2650 \mathrm{mg} \mathrm{L}^{-1}\right.$; Riley and Chester 1978), was used to define high $\mathrm{SO}_{4}{ }^{2-}$ in groundwater. Except for Aquifer 2 - 3 at site $\mathrm{CN}-3$ and Aquifer 3 at site $\mathrm{CN}-10$ where $\mathrm{SO}_{4}{ }^{2-}$ concentrations are slightly higher than $30 \mathrm{mg} \mathrm{L}^{-1}$ (i.e., $30-300 \mathrm{mg} \mathrm{L}^{-1}$ ), all the other high- $\mathrm{SO}_{4}{ }^{2-}$ waters are found to occur only in Aquifer 1. Furthermore, it is worth pointing out that the $\mathrm{SO}_{4}{ }^{2-}\left(\sim 2700-6000 \mathrm{mg} \mathrm{L}^{-1}\right)$ and $\mathrm{Cl}^{-}$ ( 25000 - $\left.45000 \mathrm{mg} \mathrm{L}^{-1}\right)$ concentrations of Aquifer 1 are mostly higher than that of common open sea water ( 2650 and $19000 \mathrm{mg} \mathrm{L}^{-1}$, respectively; Figs. 4a, b). This is not surprising because Aquifer 1 was mainly deposited in a coastal marine environment where strong evaporation was very likely to have occurred. In fact, the present annual mean evaporation $\left(\sim 1600 \mathrm{~mm} \mathrm{yr}^{-1}\right)$ is remarkably greater than the annual mean rainfall $\left(\sim 1000 \mathrm{~mm} \mathrm{yr}^{-1}\right)$ on this coastal plain. 

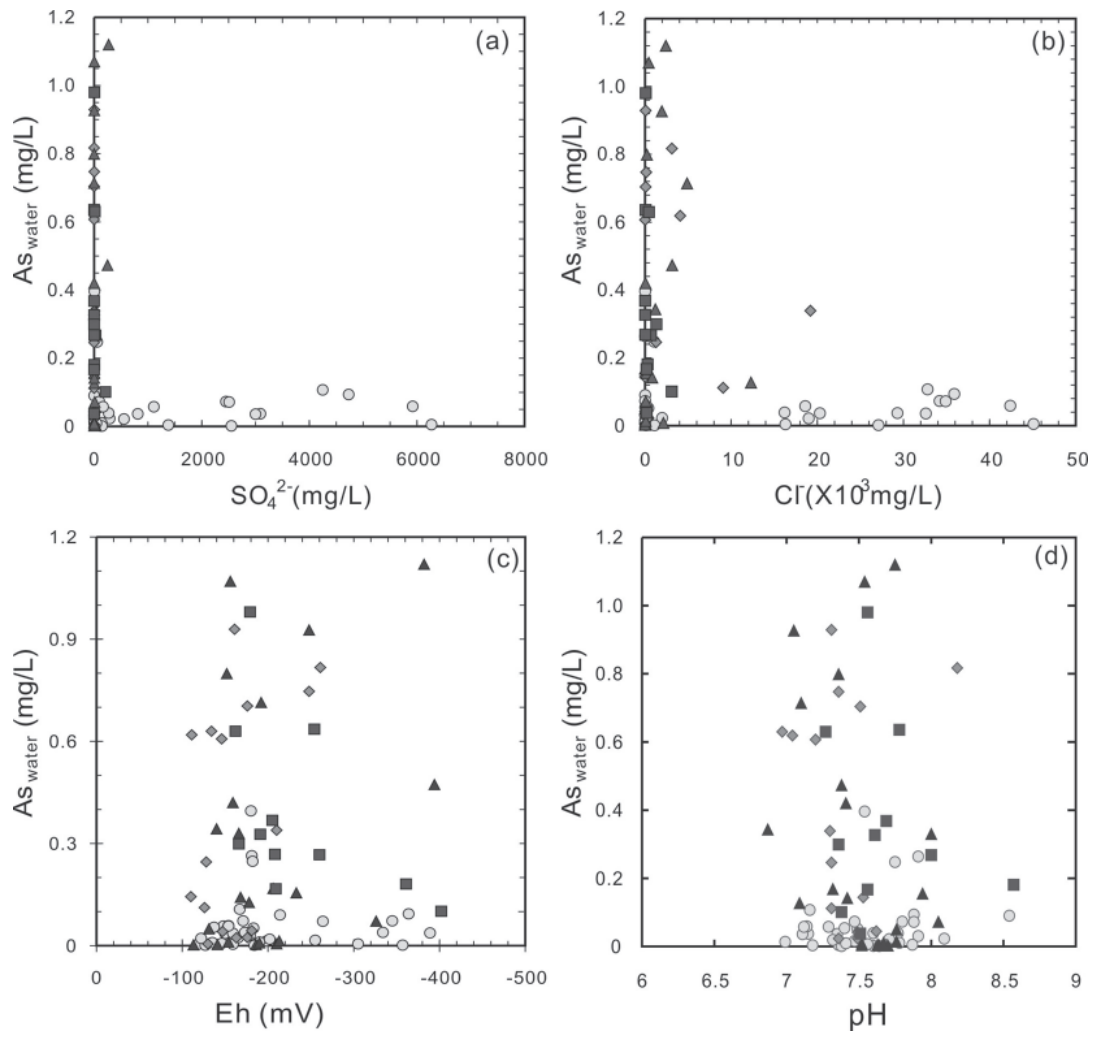

Fig. 4. Plot of As vs. $\mathrm{SO}_{4}{ }^{2-}$ (a), $\mathrm{Cl}^{-}(\mathrm{b}), \mathrm{Eh}(\mathrm{c})$, and $\mathrm{pH}$ (d) for groundwater from the Chianan plain (O: aquifer $1 ; \diamond$ : aquifer $2 ; \Delta$ : aquifer $3 ; \square$ : aquifer 4 ).

High As concentrations were demonstrated to occur only in deeper aquifers ( $>80 \mathrm{~m}$ in depth). All the groundwater samples which have higher than $0.1 \mathrm{mg} \mathrm{L}^{-1}$ of As are low in $\mathrm{SO}_{4}{ }^{2-}$ (mostly $<30 \mathrm{mg} \mathrm{L}^{-1}$; Fig. 4a) and $\mathrm{Cl}^{-}$(mostly $<2000 \mathrm{mg} \mathrm{L}^{-1}$; Fig. 4b) when compared with seawater. All the Eh values obtained are lower than $-110 \mathrm{mV}$, indicating highly reducing conditions. In fact, all the water samples were considerably reducing as indicated by common presence of characteristic $\mathrm{H}_{2} \mathrm{~S}$ odor and/or detectable amounts of HS- (TSC 2001). Most of the deep Aquifers $(2 \sim 4)$ are even more reducing as evidenced by the presence of abundant $\mathrm{CH}_{4}$ gas during pumping and sampling. However, no consistent correlation was found between As concentrations and Eh values (Fig. 4c), suggesting As concentration is not only controlled by Eh but also by other factor(s) when the environment is reducing enough with $\mathrm{Eh}<110 \mathrm{mV}$.

The $\mathrm{pH}$ values for the samples vary between 6.8 and 8.5. No significant correlation was found between As content and $\mathrm{pH}$ values (Fig. 4d), although a positive correlation between As and $\mathrm{pH}$ was previously reported (e.g., Huntsman-Mapila et al. 2006). Most of the Eh-pH data 
points are located within the $\mathrm{H}_{3} \mathrm{AsO}_{3}{ }^{\circ}$ stability field in the simplified Eh-pH diagram (Inskeep et al. 2002) for As-S- $\mathrm{H}_{2} \mathrm{O}$ system at $25^{\circ} \mathrm{C}$ based on the assumptions: $\mathrm{SO}_{4}{ }^{2-}=10^{-3} \mathrm{M}, \mathrm{H}_{3} \mathrm{AsO}_{3}{ }^{\circ}$ $=10^{-5} \mathrm{M}$ (Fig. 5). Except for the water samples from sites CN-3, 10, and 22, the samples plotted within the amorphous- $\mathrm{As}_{2} \mathrm{~S}_{3}$ domain of Fig. 5 are low in As as expected. Arsenic in both of $\mathrm{H}_{3} \mathrm{AsO}_{3}$ and $\mathrm{As}_{2} \mathrm{~S}_{3}$ is of reducing form As (III), which is in agreement with the result that As in groundwater of this plain is present largely as As (III) (Chen et al. 1994).

When molecular oxygen is not available, or when it has run up, decay of organic matter continues by a series of reactions that represent successively lower Eh values (Stumm and Morgan 1981). Sulfate reduction is a bacterial reaction in which bacteria use $\mathrm{SO}_{4}{ }^{2-}$ to oxidize organic matter to $\mathrm{CO}_{2}$. By contrast, chlorine ions are a relatively conservative constituent and are essentially not affected by biological activity. Four of the nine groundwater samples which have higher $\mathrm{Cl}^{-}$concentration than the standard seawater lie on the dilution line of seawater in the $\mathrm{SO}_{4}{ }^{2-}$ vs. $\mathrm{Cl}^{-}$diagram (Fig. 6), indicating that reduction of sulfate in the four samples was negligible. On the contrary, data points for all the other high-chlorine $\left(\mathrm{Cl}^{-}>2000 \mathrm{mg} \mathrm{L}^{-1}\right)$ groundwater samples lie below the dilution line, demonstrating the occurrence of sulfatereduction reaction after deposition of sediments.

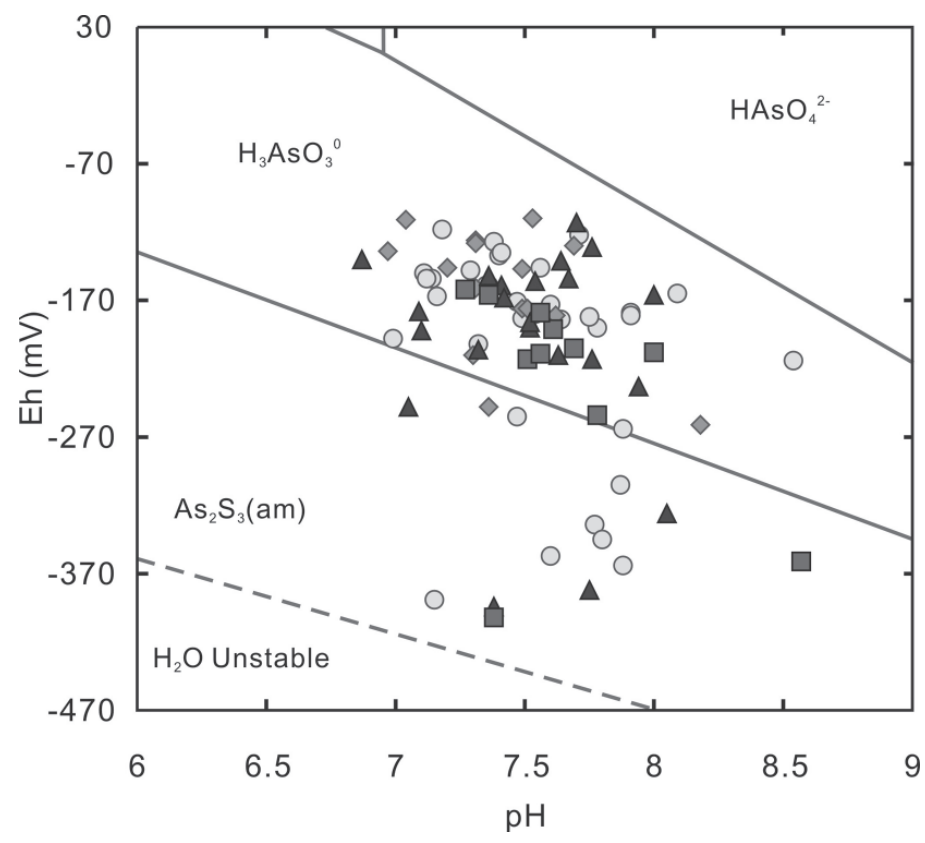

Fig. 5. Plot of Eh vs. pH for groundwaters from the Chianan plain in the simplified Eh-pH diagram for the As- $\mathrm{S}-\mathrm{H}_{2} \mathrm{O}$ system at $25^{\circ} \mathrm{C}$ constructed by Inskeep et al. (2002). The $\mathrm{SO}_{4}{ }^{2-}$ content of the samples whose Eh-pH data points fall within the $\mathrm{As}_{2} \mathrm{~S}_{3}$ (am: amorphous) field are also shown (O: aquifer $1 ; \diamond$ : aquifer $2 ; \Delta$ : aquifer 3 ; $\square$ : aquifer 4 ). 


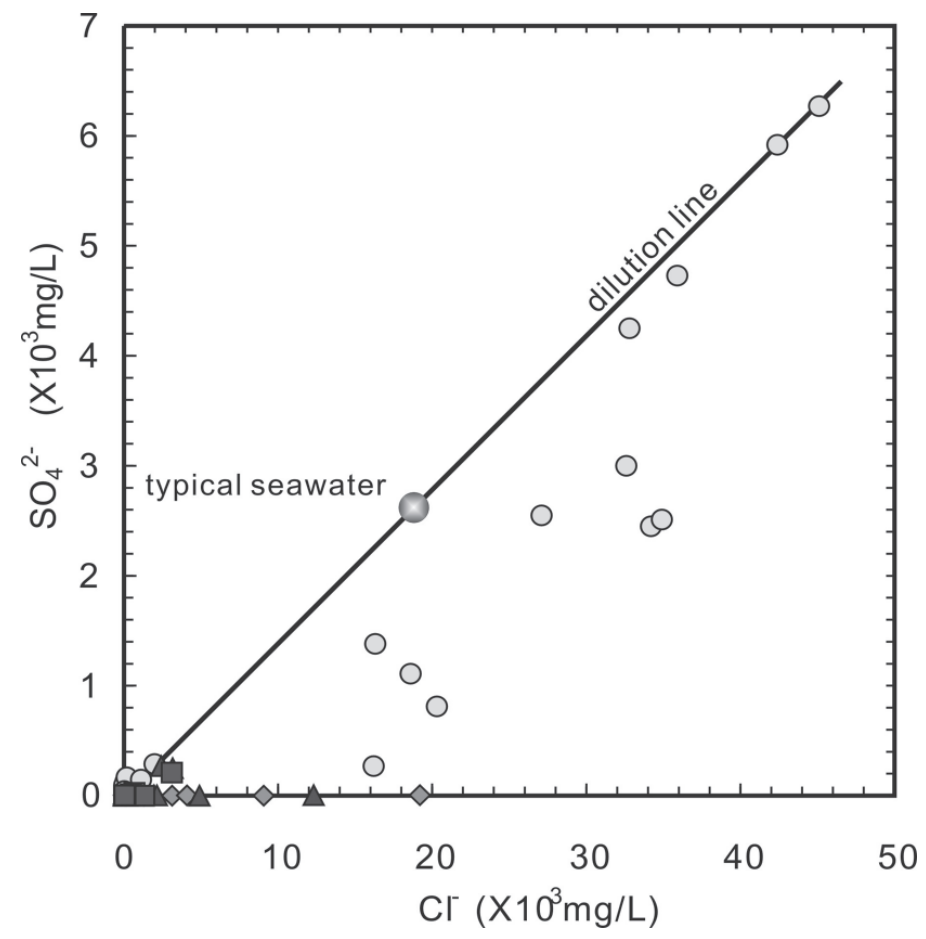

Fig. 6. Plot of $\mathrm{Cl}^{-}$vs. $\mathrm{SO}_{4}{ }^{2-}$ for groundwater from the Chianan plain. The data points for samples with $\mathrm{Cl}^{-}$contents greater than $15000 \mathrm{mg} \mathrm{L}^{-1}$ are shown (O: aquifer $1 ; \diamond$ : aquifer $2 ; \Delta$ : aquifer 3 ; $\square$ : aquifer 4 ).

As stated above, $\mathrm{SO}_{4}^{2-}$ concentrations can be reduced by microbial activity but $\mathrm{Cl}^{-}$is conservative or biologically inert. The fact that all the high-arsenic water samples are low in $\mathrm{Cl}^{-}$ content $\left(<2000 \mathrm{mg} \mathrm{L}^{-1}\right)$, as mentioned above, strongly suggests that they are either original (or only slightly diluted) fresh formation water trapped in fluvial/estuarine environments or interstitial seawater remarkably diluted after deposition. Except for the few low-arsenic samples (i.e., sample sites $\mathrm{CN}-7,18,20,24,26$, and 27) from the deep aquifers under the eastern recharging area, a slight positive correlation exists between arsenic content and mean residence time $\left({ }^{14} \mathrm{C}_{\text {DIC }}\right.$ ages) of groundwater (Fig. 7). This is in agreement with the conclusion made by Smedley and Kinniburgh (2002) and Varsányi and Kovács (2006) that a long residence time of groundwater plays an important role in As enrichment, probably implying that the rate of some As-related reactions is lower than the rate of groundwater flow. It is also worth mentioning that almost all ${ }^{14} \mathrm{C}_{\mathrm{DIC}}$ ages for water in Aquifers 2, 3, and 4 vary between 10 and $40 \mathrm{Ka}$, and are about the same as their corresponding depositional ages of sediments. This implies that the groundwater flow rates are very low as expected from the hydrogeological characteristics. The 


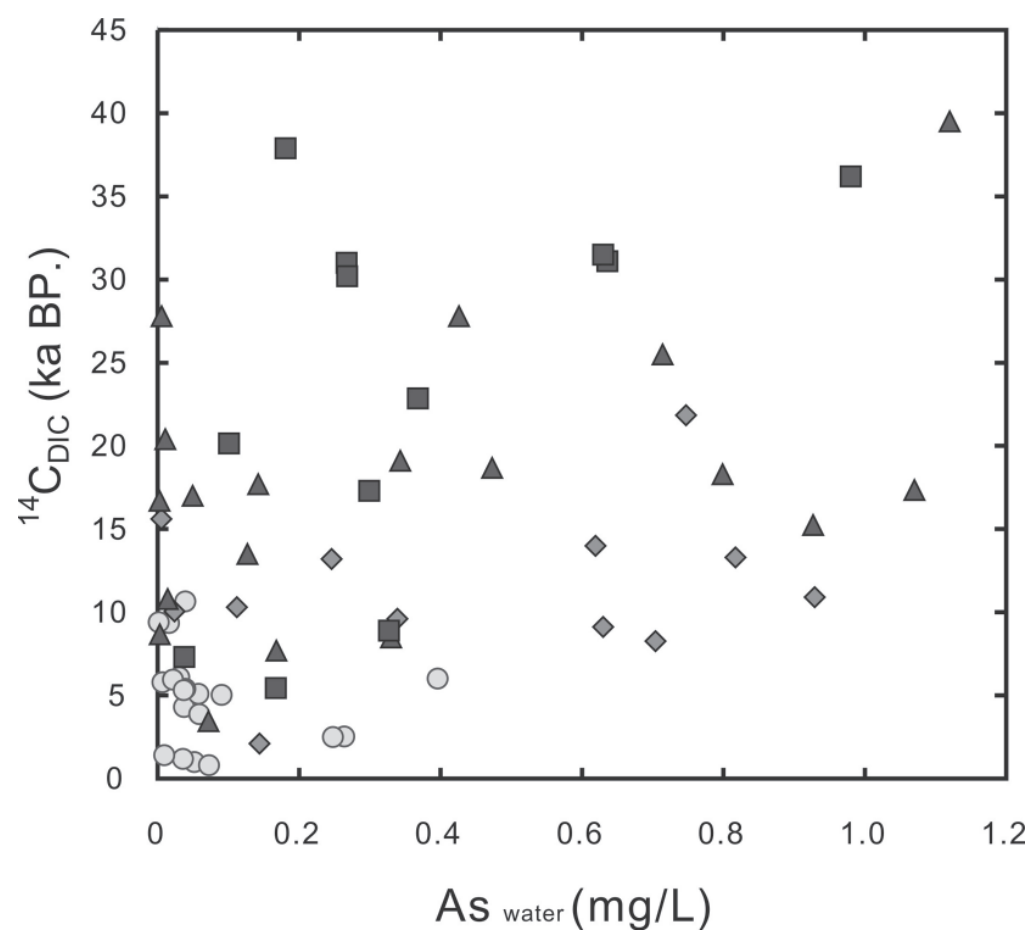

Fig. 7. Plot of ${ }^{14} \mathrm{C}_{\mathrm{DIC}}$ ages vs. As for groundwater from the Chianan plain (O: aquifer $1 ; \diamond$ : aquifer $2 ; \Delta$ : aquifer 3 ; 口: aquifer 4 ).

arsenic contents $\left(>0.1 \mathrm{mg} \mathrm{L}^{-1}\right)$ of the two samples from site CN-27 (i.e., Aquifers 1 and 3) are higher than that of the neighboring aquifers. This may be attributed to the more complicated topographic relief inferred from the unconformity (e.g., site CN-28; Fig. 2) between the Holocene strata and its underlying late Pleistocene basement in the northeastern part.

Many studies have shown that hydroxyl groups on the surface of many minerals are the most abundant and reactive adsorption sites, and consequently, oxides and hydroxides (Fe, $\mathrm{Mn}$, and $\mathrm{Al}$ ) have a strong affinity for As (V) under an oxic environment (e.g., Pierce and Moore 1982; Bowell 1994).

Detailed results on lithology, arsenic concentrations extracted by the mixture of phosphoric acid and hydroxylamine hydrochloride ( $\mathrm{PHH}$ solution), and depositional environments for the core sediments from site $\mathrm{CN}-1$ and site $\mathrm{CN}-23$ are shown in Fig. 8. Apparently, no preferred relationship between extractable arsenic concentrations and different depositional facies can be inferred.

It was noted that oxidation of mineral sulfides can be very rapid leading to the formation of iron oxide and this would cause misleading results (Breit et al. 2006). Despite the efforts we 

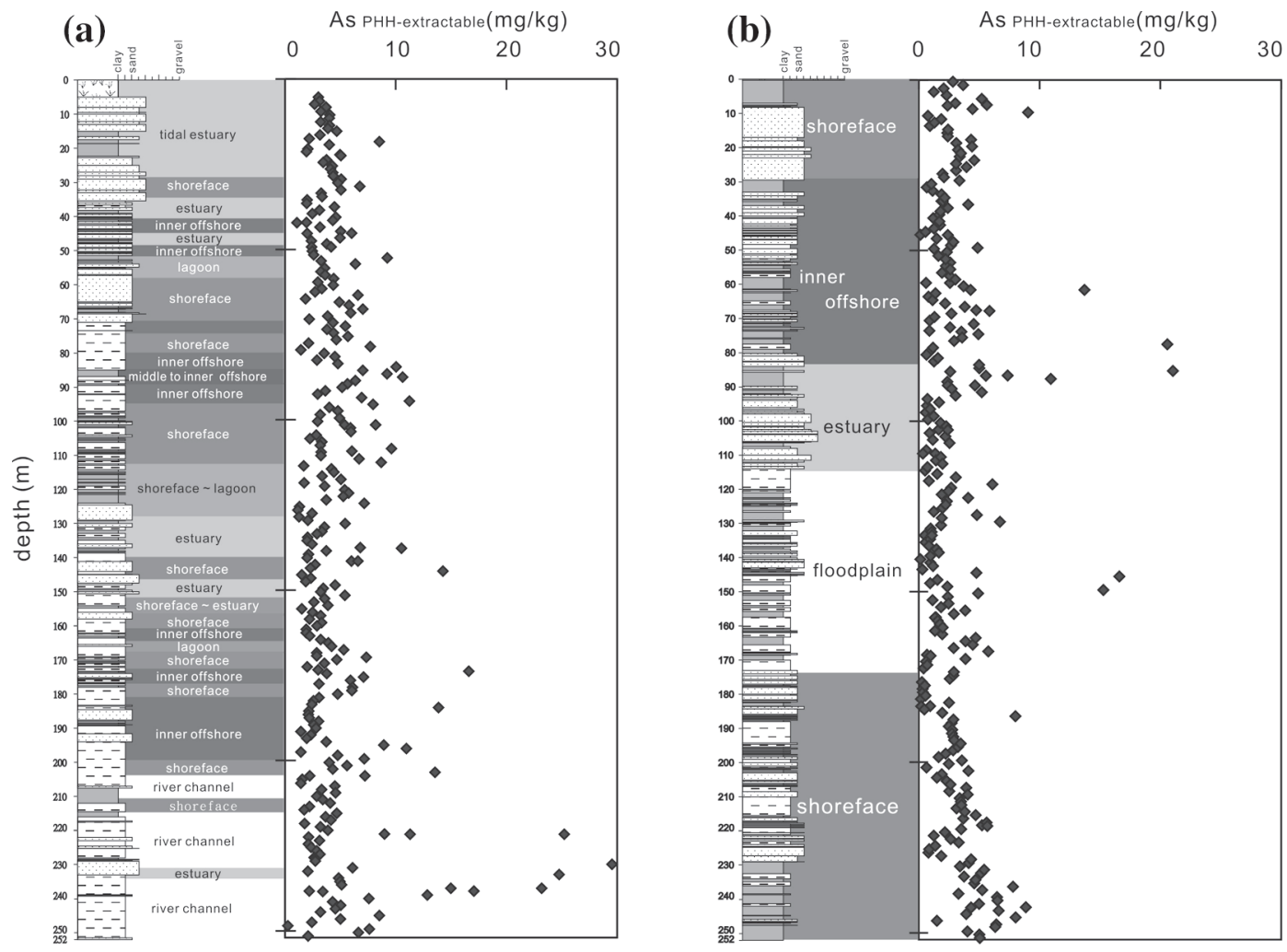

Fig. 8. Column profiles of arsenic contents extracted by a mixture of phosphoric acid and hydroxylamine hydrochloride $(\mathrm{PHH})$ for core sediments from $\mathrm{CN}-1$ (A) and $\mathrm{CN}-23(\mathrm{~B})$.

made to keep the reduced sediment anaerobic, brief contact with the atmosphere did occur. Ngiam and Lim (2001) and Gómez-Ariza et al. $(1999,2000)$ also pointed out the limitations of sequential extraction. Accordingly, we summed up the arsenic contents obtained from the three-stage sequential extraction scheme for each sample (Fig. 9a) to operationally quantify the total extractable arsenic in the easily exchangeable, Fe-(hydr)oxides, sulfides and organic matter phases (Fig. 9b). In fact, the sequentially extracted total arsenic content is fundamentally the same as that obtained from $\mathrm{PHH}$ extraction for samples collected from the same sample (Fig. 9c) and the amount of arsenic extracted from organic matter is negligible as compared with that from Fe-(hydr)oxides. In short, mobile arsenic in the sediments of the Chianan plain was demonstrated to be dominantly associated with clay-sized Fe-(hydr)oxides.

Although there exists a good correlation between total extractable arsenic and $\mathrm{Fe}$ in sediments (Fig. 9d), no simple relationship was found between the contents of As and Fe in ground- 

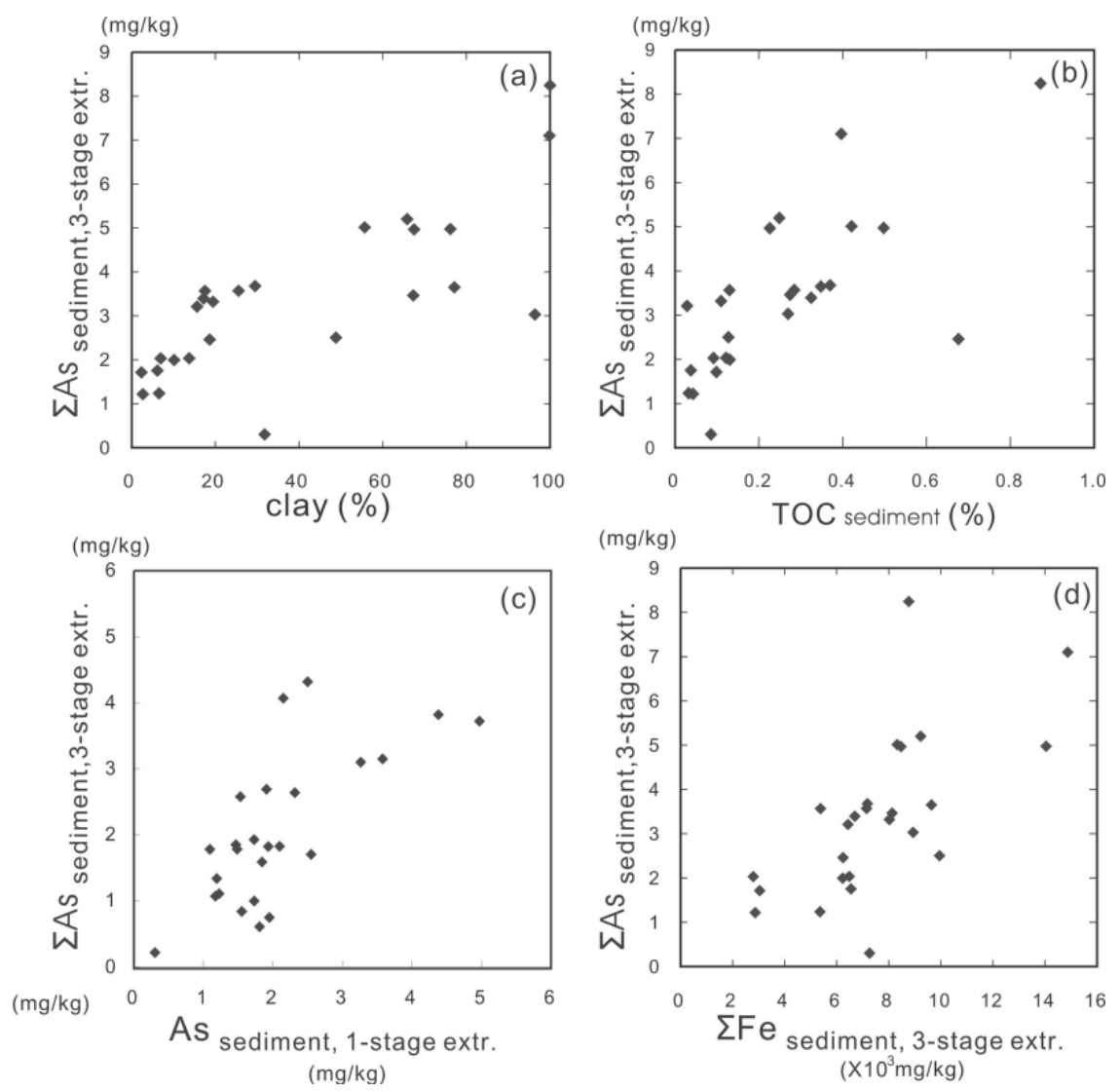

Fig. 9. Plot of (a) total 3 stage-extractable arsenic vs. proportion of clay-size fraction; (b) total 3-stage-extractable As vs. total organic matter; (c) total 3 stage-extractable arsenic vs. 1 stage-extractable arsenic; and (d) total 3 stage-extractable arsenic vs. total 3 stage-extractable iron in sediments from the Chianan plain.

water (Fig. 10a). This suggests that Fe and As contents were further modified after the two elements were released into water. We found that the $\mathrm{SO}_{4}{ }^{2-}$ vs. Fe diagram of groundwater (Fig. 10b) shows a characteristic pattern similar to that of As vs. Fe. It has been well known that redox conditions are important in controlling the chemistry of metals ions and solids (for example, $\mathrm{Fe}^{2+}$ and $\mathrm{Fe}_{2} \mathrm{O}_{3}$ ), species or solids containing sulfur (for example, $\mathrm{SO}_{4}{ }^{2-}, \mathrm{H}_{2} \mathrm{~S}$, and $\mathrm{FeS}_{2}$ ), and dissolved gases containing carbon (for example, $\mathrm{CH}_{4}$ ). There is a general trend of abundance in the above-mentioned species as the environment becomes more reducing (Appelo and Postma 1994). Based on the diagrams of $\mathrm{As}$ vs $\mathrm{Fe}$ and $\mathrm{SO}^{2-}$ vs. Fe, the groundwater samples 

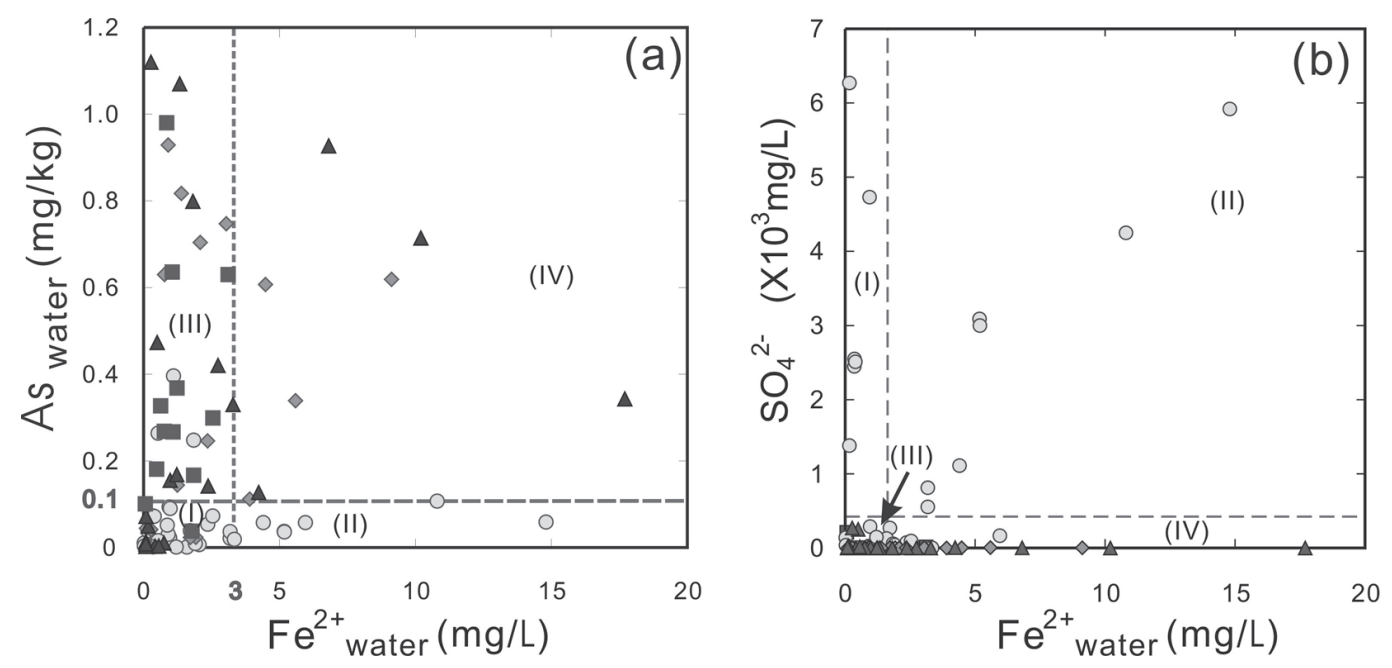

Fig. 10. Plot of As vs. Fe for groundwater from the Chianan plain. The water samples are classified into four groups ( $\sim$ IV) as is also shown in Fig. 11 in terms of relative contents of $\mathrm{As}$ and $\mathrm{Fe}^{2+}(\mathrm{a})$, and relative $\mathrm{SO}_{4}{ }^{2-}$ and $\mathrm{Fe}^{2+}(\mathrm{b})$.

analyzed can be generally classified into four groups with increasing reduction potential (Chen 2007; Fig. 11). Group I samples are very low in As and $\mathrm{Fe}$, but high in $\mathrm{SO}_{4}{ }^{2-}$. Most of them were drawn from the oxic or less reductive shallow Aquifer 1, but this group also includes those low- $\mathrm{SO}_{4}{ }^{2-}$ samples drawn from the aquifers in the eastern recharge areas. Group II samples are low-medium in As, but high in $\mathrm{Fe}$ and $\mathrm{SO}_{4}{ }^{2-}$. No positive correlation was found between $\mathrm{As}$ and $\mathrm{Fe}$ contents, probably because arsenic $(\mathrm{V})$ reduction would normally be expected to occur after $\mathrm{Fe}^{3+}$ reduction but before $\mathrm{SO}_{4}{ }^{2-}$ reduction (Smedley and Kinniburgh 2002). Group III samples are relatively very high in As, but very low in $\mathrm{Fe}$ and $\mathrm{SO}_{4}{ }^{2-}$ due to the precipitation of iron sulfides. Dissolved As concentrations remain high because As is complexed by dissolved humic substances (Lu 1990b; Chen et al. 1994). Group IV samples are high in As and Fe, but very low in $\mathrm{SO}_{4}{ }^{2-}$ because all $\mathrm{SO}_{4}{ }^{2-}$ was reduced. It is noted that the concentrations of $\mathrm{As}, \mathrm{Fe}$, and $\mathrm{SO}_{4}^{2-}$ of these four groups fundamentally reflect different stages in the sequence of reduction processes of groundwater as aquifer depth increases (Fig. 11). Of course, a few samples are transitional in terms of the characterization of As occurrences.

\section{CONCLUSIONS}

This study demonstrates that all the arsenic concentrations of the analyzed groundwater samples from the Chianan coastal plain exceed $0.01 \mathrm{mg} \mathrm{L}^{-1}$, with the highest value up to $\sim 1.2 \mathrm{mg} \mathrm{L}^{-1}$. Almost all the high arsenic waters $\left(>0.10 \mathrm{mg} \mathrm{L}^{-1}\right)$ occur only in deep aquifers $(>50 \mathrm{~m})$ deposited 


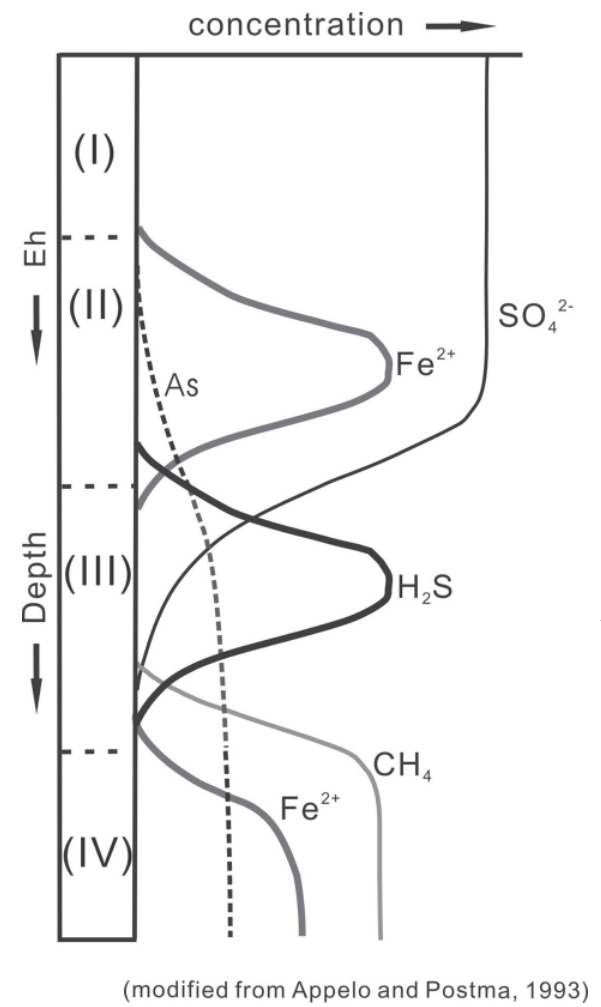

Fig. 11. Schematic diagram of the distribution of As concentrations in the groundwater of the Chianan plain, with respect to the variation of some indicative species in the sequence of reduction processes for groundwater (Appelo and Postma 1994). The designation of composition or redox zonations I IV correspond to that of Fig. 10.

before the Holocene transgression and are low in $\mathrm{SO}_{4}{ }^{2-}\left(\right.$ mostly $\left.<2 \mathrm{mg} \mathrm{L}^{-1}\right)$ under highly reducing conditions $(\mathrm{Eh}<-110 \mathrm{mV})$. The amounts of acid extractable arsenic show positive correlation with the proportion of clay-sized Fe-(hydr)oxides in the sediments. The concentrations of As, $\mathrm{Fe}$, and $\mathrm{SO}_{4}{ }^{2-}$ of the water samples analyzed can be classified into four groups, which reflect developing stages in the sequence of reduction processes of common groundwater. It is suggested that the reductive dissolution of As-rich Fe-(hydr)oxides is the major source of As in the groundwater, but the contents of $\mathrm{SO}_{4}{ }^{2-}$, dissolved humic substances and residence time of groundwater, and the proportion of clay-sized Fe-(hydr)oxides, are also responsible for dissolved As in the Chianan coastal plain. The characteristic occurrences of As and humic substances were in turn caused by the relatively low flow-rate and long residence time, as indicated by relatively old ${ }^{14} \mathrm{C}_{\mathrm{DIC}}$ ages, of groundwater in fine-grained sediments deposited in the flat coastal plain.

Acknowledgements The authors gratefully acknowledge Prof. Y. N. Shieh of Purdue University, Indiana, USA, Prof. Y. G. Chen of National Taiwan University and anonymous reviewers for their useful comments and improvement of the manuscript. We also thank the Central Geological Survey, Ministry of Economic Affairs (ROC) for providing sediment core samples and related geological information, and the Groundwater Exploitation and Conserva- 
tion Center and Taiwan Sugar Company for helping in water sampling. This study is supported financially by National Science Council, Republic of China (NSC94-2116-M-002-004).

\section{REFERENCES}

Ahmed, K. M., P. Bhattacharya, M. A. Hasan, S. H. Akhter, M. Alam, M. A. H. Bhuyian, M. B. Imam, A. A. Khan, and O. Sracek, 2004: Arsenic enrichment in groundwater of the alluvial aquifers in Bangladesh: An overview. Appl. Geochem., 19, 181-200.

Anawar, H. M., J. Akai, K. Komaki, H. Terao, T. Yoshioka, T. Ishizuka, S. Safiullah, and K. Kato, 2003: Geochemical occurrence of arsenic in groundwater of Bangladesh sources and mobilization processes. J. Geochem. Explor., 77, 109-131.

Appelo, C. A. J., and D. Postma, 1994: Geochemistry, Groundwater and Pollution. Balkema, A. A., Rotterdam, the Netherlands, 535 pp.

Bowell, R. J., 1994: Sorption of arsenic by iron oxides and oxyhydroxides in soils. Appl. Geochem., 9, 279-286.

Breit, G. N., J. C. Yount, M. N. Uddin, A. A. Muneem, H. A. Lowers, R. L. Driscoll, and J. W. Whitney, 2006: Compositional Data for Bengal Delta Sediment Collected from Boreholes at Srirampur, Kachua, Bangladesh: US Geological Survey Open-File Report 2006$1222,51 \mathrm{pp}$.

Chen, C. J., T. L. Kuo, and M. M. Wu, 1988: Arsenic and cancers. Lancet, 414-415.

Chen, K. P., and H. Y. Wu, 1962: Epidemiologic studies on blackfoot disease: 2. A study of source of drinking water in relation to the disease. J. Formosan Med. Assoc., 61, 611618.

Chen, K. Y., 2007: Migration and Enrichment of Arsenic in Groundwater in the Chianan Coastal Plain, Southwestern Taiwan. Ph.D. Thesis, National Taiwan University, Taipei, Taiwan, ROC, 164 pp.

Chen, S. L., S. R. Dzeng, M. H. Yang, K. H. Chiu, G. M. Shieh, and C. M. Wal, 1994: Arsenic species in groundwaters of the Blackfoot disease areas, Taiwan. Environ. Sci. Technol., 28, 877-881.

Ellwood, M. J., and W. A. Maher, 2003: Measurement of arsenic species in marine sediments by high-performance liquid chromatography-inductively coupled plasma mass spectrometry. Anal. Chem. Acta., 477, 279-291.

Gómez-Ariza, J. L., I. Giráldez, D. Sánchez-Rodas, and E. Morales, 1999: Metal readsorption and redistribution during the analytical fractionation of trace elements in oxic estuarine sediments. Anal. Chim. Acta, 399, 295-307.

Gómez-Ariza, J. L., I. Giráldez, D. Sánchez-Rodas, and E. Morales, 2000: Comparison of the feasibility of three extraction procedures for trace metal partitioning in sediments from south-west Spain. Sci. Total Environ., 246, 271-283.

Hackley, C. K., C. L. Liu, and D. D. Coleman, 1992: ${ }^{14} \mathrm{C}$ dating of groundwater containing microbial $\mathrm{CH}_{4}$. In: Long, A., and R. S. Kra (Eds.), Proceedings of the $14^{\text {th }}$ International ${ }^{14} \mathrm{C}$ Conference, Radiocarbon, 34, 686-695.

Hering, J. G., and P. E. Kneebone, 2001: Biogeochemical controls on arsenic occurrence and 
mobility in water supplies. In: Frankenberger, W. T. Jr. (Ed.), Environmental Chemistry of Arsenic, Marcel Dekker Publ., New York, USA, 155-181.

Ho, C. S., 1986: An introduction to the geology of Taiwan: Explanatory text of the geologic map of Taiwan. Cent. Geol. Survey, Taiwan.

Huntsman-Mapila, P., T. Mapila, M. Letshweny, P. Wolski, and C. Hemond, 2006: Characterization of arsenic occurrence in the water and sediments of the Okavango Delta, NW Botswana. Appl. Geochem., 21, 1376-1391.

Inskeep, W. P., T. R. McDermott, and S. Fendorf, 2002: Arsenic (V) / (III) Cycling in soils and natural waters: chemical and microbiological processes. In: Frankenberger, W. T. Jr. (Ed.), Environmental Chemistry of Arsenic, Marcel Dekker Publ., New York, USA, 183-215.

Kao, T. M., and S. R. Kao, 1954: Studies on the cause of a particular dry gangrene. J. Formosan Med. Assoc., 53, 272. (the Abstract)

Keon, N., C. H. Swartz, D. J. Brabander, C. Harvey, and H. F. Hemond, 2001: Validation of an arsenic sequential extraction method for evaluating mobility in sediments. Environ. Sci. Technol., 35, 2778-2784.

Li, X. D., B. J. Coles, M. H. Ramsey, and I. Thornton, 1995: Sequential extraction of soils for multi-element analysis by ICP-AES. Chem. Geol., 124, 109-123.

Liu, T. K., 1995: Estimating flow and recharge rates of groundwater in western Taiwan using radiocarbon and tritium. Proceedings of the $15^{\text {th }}$ International ${ }^{14} \mathrm{C}$ Conference, Radiocarbon, 37, 531-542.

Liu, T. K., Q. C. Sung, K. Y. Chen, Z. L. Pi, C. H. Yang, and P. H. Cheng, 1997: Tectonic subsidence and uplift in the Zeikang-Hopi area of southwestern Taiwan since the late Pleistocene. J. Geol. Soc. China, 40, 155-165.

Lu, F. J., C. K. Yang, and K. H. Lin, 1975: Physico-chemical characteristics of drinking water in blackfoot disease endemic areas in Chia-I and Tainan Hsiens. J. Formosan Med. Assoc., 74, 596-605.

Lu, F. J., 1990a: Blackfoot disease: Arsenic or humic acid? Lancet, 336, 115-116.

Lu, F. J., 1990b: Fluorescent humic substances and blackfoot disease in Taiwan. Appl. Organometall. Chem., 4, 191-195.

Mandal, B. K., and K. T. Suzuki, 2002: Arsenic round the world: A review. Talanta, 58, 201-235.

Montperrus, M., Y. Bohari, M. Bueno, A. Astruc, and M. Astruc, 2002: Comparison of extraction procedures for arsenic speciation in environmental solid reference materials by high-performance liquid chromatography-hydride generation-atomic fluorescence spectroscopy. Appl. Organometall. Chem., 16, 347-354.

Ngiam, L. S., and P. E. Lim, 2001: Speciation patterns of heavy metals in tropical estuarine anoxic and oxidized sediments by different sequential extraction schemes. Sci. Total Environ., 275, 53-61.

Oung, J. N., Y. D. Lin, S. Y. Lin, Q. C. Sung, T. K. Liu, and C. H. Yang, 2001: Organic geochemistry of sediments in the southeastern coastal plain, Taiwan. West. Pacific Earth Sci., 1, 373-390.

Pedersen, H. D., D. Postma, and R. Jakobsen, 2006: Release of arsenic associated with the reduction and transformation of iron oxides. Geochim. Cosmochim. Acta, 70, 4116-4129. 
Pierce, M. L., and C. B. Moore, 1982: Adsorption of As (III) and As (V) on amorphous iron hydroxide. J. Water Res., 16, 1247.

Reineck, H. E., and I. B. Singh, 1980: Depositional Sedimentary Environments, $2^{\text {nd }}$ Ed., Springer-Verlag, New York, USA.

Riley, J. P., and R. Chester (Eds.), 1978: Chem. Oceanogr., $2^{\text {nd }}$ Ed., Academic Press, New York.

Smedley, P. L., and D. G. Kinniburgh, 2002: A review of the source, behavior and distribution of arsenic in natural waters. Appl. Geochem., 17, 517-568.

Stumm, W., and J. J. Morgan, 1981: Aquatic Chem. $2^{\text {nd }}$ Ed., Wiley-Interscience, New York, USA.

Teng, L. S., 1987: Stratigraphic record of the late Cenozoic Penglai Orogeny of Taiwan. Acta Geol. Taiwan., 25, 205-224.

Tessier, A., P. G. C. Campbell, and M. Bisson, 1979: Sequential extraction procedure for speciation of particular trace metals. Anal. Chem., 51, 844.

TSC (Taiwan Sugar Company), 2001: Groundwater Quality by the Taiwan Groundwater Monitoring Network (3/5). Taiwan Water Resource Bureau.

Tseng, W. P., W. Y. Chen, J. L. Sung, and J. S. Chen, 1961: A clinical study of Blackfoot disease in Taiwan: An endemic peripheral vascular disease. Mem. Coll. Med., Natl. Taiwan Univ., 3, 1-8.

Varsányi, I., and L. O. Kovács, 2006: Arsenic, iron and organic matter in sediments and groundwater in the Pannonian Basin, Hungary. Appl. Geochem., 21, 949-963.

Wu, L. C., 1999: Depositional environments and stratigraphic correlation of sediments in the Chianan plain, SW Taiwan. Final Report, Cent. Geol. Surv., MOEA, ROC.

Chen, K. Y., and T. K. Liu, 2007: Major factors controlling arsenic occurrence in the groundwater and sediments of the Chianan coastal plain, SW Taiwan. Terr. Atmos. Ocean. Sci, 18, 975-994, doi: 10.3319/TAO.2007.18.5.975(TT). 